\title{
EVALUASI KINERJA PENGAWAS SEKOLAH DALAM MENINGKATKAN MUTU PENDIDIKAN MELALUI SUPERVISI PENDIDIKAN
}

\author{
Heru Herdianto \\ Email : heruherdian011@gmail.com
}

\begin{abstract}
ABSTRAK
Pengajaran sangat tergantung pada kemampuan mengajar guru, maka kegiatan supervisi menaruh perhatian utama pada peningkatan kemampuan profesional guru, yang pada gilirannya akan meningkatkan mutu proses belajar mengajar. Supervisi yang dilakukan pengawas Pendidikan Agama Islam cukup efektif dalam meningkatkan Kompetensi pedagogik guru terlihat dari meningkatnya penguasaan guru terhadap teori belajar dan prinsip pembelajaran, efektivitas guru dalam pembelajaran yang mendidik, dan fasilitasi pengembangan potensi peserta didik.

Evaluasi terhadap hasil supervisi adalah Kinerja pengawas Sekolah masih belum maksimal meningkatnya kompetensi pedagogik guru terlihat dari meningkatnya penguasaan guru terhadap teori belajar dan prinsip pembelajaran, efektivitas guru dalam pembelajaran yang mendidik, dan fasilitasi pengembangan potensi peserta didik Hasil supervisi akademik, menunjukkan bahwa guru dapat dikatakan profesional karena hasil nilai empat guru berada pada kategori baik Evaluasi pembimbingan dan pelatihan yang dilakukan oleh pengawas ternyata menujukan hasil yang positif dari pihak sekolah, guru maupun siswa.
\end{abstract}

Kata Kunci : Evaluasi Pengawas Sekolah, kinerja pengawas sekolah

\section{Latar Belakang}

Istilah supervisi pendidikan sudah cukup lama dikenal dalam dunia pendidikan di Indonesia. Pengertian supervisi pendidikan pada umumnya mengacu kepada usaha perbaikan situasi belajar mengajar. Akan tetapi nampaknya masih terdapat banyak keragaman pendapat dalam menafsirkan istilah tersebut. Dan hal ini akan membawa implikasi yang berbeda pula dalam pelaksanaannya, bahwa pada hakekatnya supervisi pendidikan dapat diartikan sebagai bimbingan profesional bagi guru-guru.Bimbingan profesional yang dimaksudkan adalah segala usaha yang memberikan kesempatan bagi guru-guru untuk berkembang secara profesional, sehingga mereka lebih maju lagi dalam melaksanakan tugas pokoknya, yaitu memperbaiki dan meningkatkan proses belajar murid-murid.

Suatu pengajaran sangat tergantung pada kemampuan mengajar guru, maka kegiatan supervisi menaruh perhatian utama pada peningkatan kemampuan profesional guru, yang pada gilirannya akan meningkatkan mutu proses belajar mengajar. Dalam analisis terakhir, kualitas supervisi akan direfleksikan pada peningkatan hasil belajar murid.Seorang supervisor apakah dia Kepala Sekolah, penilik Sekolah atau pengawas dalam melaksanakan supervisi hendaknya berlandaskan pada prinsip-prinsip supervisi. Pelaksanaan supervisi yang dilaksanakan pengawas sekolah belum terprogram, sehingga pengawas sekolah belum sepenuhnya dapat meningkatkan profesionalisme guru. Supervisi yang dilakukan pengawas Pendidikan Agama Islam cukup efektif dalam meningkatkan Kompetensi pedagogik guru terlihat dari meningkatnya penguasaan guru terhadap teori belajar dan prinsip pembelajaran, efektivitas guru dalam pembelajaran yang mendidik, dan fasilitasi pengembangan potensi 
peserta didik. Evaluasi penyusunan program pengawas dilaksanakan sangat efektif sesuai dengan perencanaan program supervisi sebagaimana terlampir pada program kerja pengawas yakni melakukan pengawasn setiap semesteran, triwulan dan bulanan Evaluasi pelaksanaan program oleh pengawasan di Kecamatan Telaga Biru sudah dilaksanakan secara baik sesuai dengan aturan dan pedoman yang ada setiap pengawas, Evaluasi pembimbingan dan pelatihan yang dilakukan oleh pengawas ternyata menujukan hasil yang positif dari pihak sekolah, guru maupun siswa.

Supervisi pendidikan berkembang seiring berkembangkan ilmu manajemen. Pada awal perkembangannya, supervisi dilakukan dengan pendekatan inspeksi. Supervisor datang ke sekolah dan mengamati guru mengajar. Fokus perhatian supervisor adalah menemukan kesa berdasarkan standar kerja baku yang dirumuskan sedemikian rupa oleh otoritas pendidikan. Guru melaksanakan tugas sesuai dengan prosedur operasional yang standar. Supervisor dengan guru merupakan dua pihak sebagai atasan Supervisor memiliki tingkat kebenaran yang lebih tinggi dari pada guru. Seiring dengan perkembangan manajemen bahwa produktivitas ditentukan juga oleh hubungan sosial antar pekerja dan dengan supervisor. Pendekatan supervisi bergerak ke arah yang lebih demokratis; supervisor dan guru dapat saling bertukar pendapat tentang peningkatan kualitas pembelajaran. Perkembangan supervisi dewasa ini lebih menekankan kepada upaya guru untuk mengembangkan kualitas pembelajarannya melalui pengembangan keprofesionalan berkelanjutan. Sehubungan perkembangan pengetahuan dan teknologi yang berkembangan pesat dalam waktu yang sangat singkat, supervisor dengan jumlahyang sangat terbatas dan dengan kemampuan yang variatif sehingga tidak mampu melayani kebutuhan supervisi guru dalam jumlah yang besar. Guru perlu berinisiatif menganalisis kualitas pembelajaran dan menemukan permasalahan pembelajaran untuk diupayakan peningkatan kualitasnya secara berkelanjutan. Supervisor lebih berperan sebagai fasilitator untuk terjadinya pengembangan keprofesionalan guru secara berkelanjutan tersebut. Di samping itu, menumbuhkan motivasi guru yang tinggi untuk selalu meningkatan keprofesionalannya.

Berdasarkkan uraian diatas maka permasalahan dalam tulisan ini adalah (1)Apa saja permasalahan supervisi pendidikan di Indonesia? (2)Bagaimana solusi untuk mengatasi permasalahan supervisi pendidikan di Indonesia? Tujuan Penulisan makalah ini adalah untuk melihat bagaimana penerapan supervisi pendidikan di Indonesia, apakah sudah sesuai dengan seharusnya terjadi atau masih banyak kekurangan dalam impelemnetasi supervisi pendidikan di indonesia, dan bagaimana melihat implementasi supervisi pendidikan.

\section{PEMBAHASAN}

Jika pengawas dalam melaksanakan supervisinya belum menyusun program, sangatlah wajar bila pengawas sekolah belum sepenuhnya dapat meningkatkan mutu sekolah termasuk profesionalisme kepala sekolah dan guru. Program supervisi terdiri dari perencanaan, pelaksanaan dan evaluasi. Dari hasil penelitian ternyata belum ada program tindak lanjut yang dirancang oleh pengawas. Dalam menyusun program supervisi bagi sekolah binaan, terdapat pengawas yang menyusun program bekerja sama dengan kepala sekolah binaan dengan demikian akan terdapat variasi program supervisi pengawas di sekolah satu dengan yang lainnya. Program supervisi yang disusun memperhatikan visi, misi dan tujuan sekolah binaan. Dalam penyusunan program supervisi, para pengawas mendasarkan Peraturan Menteri Pendidikan Nasional Republik Indonesia Nomor 12 Tahun 2007.

Evaluasi terhadap hasil supervisi adalah Kinerja pengawas Sekolah masih belum maksimal meningkatnya kompetensi pedagogik guru terlihat dari meningkatnya penguasaan guru terhadap teori belajar dan prinsip pembelajaran, efektivitas guru dalam pembelajaran yang mendidik, dan fasilitasi pengembangan potensi peserta didik Hasil supervisi akademik, 
menunjukkan bahwa guru dapat dikatakan profesional karena hasil nilai empat guru berada pada kategori baik Evaluasi pembimbingan dan pelatihan yang dilakukan oleh pengawas ternyata menujukan hasil yang positif dari pihak sekolah, guru maupun siswa. Evaluasi pelaksanaan program pengawas secara langsung belum bisa memenuhi standar evaluasi dan monitoring yang dilaksanakan oleh pengawas baik secara periodik atau kontinyu sesuai dengan lembar kerja pengawas. Masih terdapat beberapa kekurangan yang menjadi perhatian umum yakni pelaksanaan kunjugan ke sekolah belum sesuai dengan jadwal yang telah ditetapkan. satu orang pengawas harus melakukan pengawasan terhadap 16 Sekolah Menengah Atas kurangnya tenaga pengawas, banyaknya guru yang harus dibina dan kurangnya intensitas supervisi sehingga pelaksanaan kunjugan ke sekolah belum bisa sesuai dengan jadwal yang telah ditetapkan.

Dalam menyusun program supervisi bagi sekolah binaan, terdapat pengawas yang bekerja sama dengan kepala sekolah binaan, dengan demikian akan terdapat variasi program supervisi pengawas di sekolah satu dengan yang lainnya. Program supervisi yang disusun memperhatikan visi, misi dan tujuan sekolah binaan.

\section{PENUTUP}

\section{KESIMPULAN}

Berdasarkan pembahasan di atas, maka dapat disimpulkan bahwa Belum maksimalnya hasil dan dampak supervisi oleh pengawas sehingga belum bisa memenuhi standar ternyata terkait dengan banyaknya kekurangan dan/kendala dalam pelaksanaannya. Adapun faktor penghambat pelaksanaan suvervisi yang dilakukan oleh pengawas yaitu kondisi geografis (di wilayah kepulauan) serta belum memadainya sarana dan prasarana umum , kurangnya tenaga pengawas, banyaknya guru yang harus dibina dan kurangnya intensitas supervisi, satu orang pengawas harus melakukan pengawasan terhadap 16 Sekolah Menengah Atas, kurangnya tenaga pengawas, banyaknya guru yang harus dibina dan kurangnya intensitas supervisi sehingga pelaksanaan kunjugan ke sekolah belum bisa sesuai dengan jadwal yang telah ditetapkan. Kurangnya kemampuan pengawas sekolah dalam menyusun program supervise, Selain itu, tenaga pengawas yang tidak sesuai dengan masingmasing bidang studi, ketidaksesuaian latar belakang pendidikan antara pengawas dan guru. Langkah supervisi yang dilakukan oleh pengawas sekolah seperti berikut ini. Ternyata ada 2 versi pengawas dalam melaksanakan pengawasan terhadap sekolah binaan baik terhadap kepala sekolah maupun guru: tidak terprogram dan telah terprogram, walaupun begitu belum ada program tindak lanjut.

\section{SARAN}

Saran agar maksimalnya hasil kinerja pengawas, satu orang pengawas harus melakukan pengawasan satu Sekolah Menengah, guru harus dibina dan ditingkatkan intensitas supervisi sehingga pelaksanaan kunjugan ke sekolah bisa sesuai dengan jadwal yang telah ditetapkan.

\section{DAFTAR PUSTAKA}

Slameto, S. (2017). Supervisi Pendidikan Oleh Pengawas Sekolah. Kelola: Jurnal

Manajemen Pendidikan, 3(2), 192. https://doi.org/10.24246/j.jk.2016.v3.i2.p192-206

Sola, E. (2018). Ada Apa Dengan Supervisi Pendidikan? Jurnal Idaarah, II(1), 130-140. 
Sabandi, A. (2013). Supervisi Pendidikan Untuk Pengembangan Profesionalitas Guru Berkelanjutan. Jurnal Ilmiah Ilmu Pendidikan, XIII(2), 1-9.

Pendahuluan, A. (1981). A . Fungsi-fungsi dan tujuan supervisi pendidikan 1 . Fungsi Supervisi Pendidikan. 